\title{
COMPARATIVE STUDIES ON NUTRITIVE ANALYSIS AND CULTIVATION OF FOUR AZOLLA SPECIES
}

\author{
Darsi Phebe Sarah Koti Ratnam* \\ Department of Botany \& Microbiology, Andhra Christian College, Guntur, Andhra \\ Pradesh, India.
}

Email: phebesarah63@gmail.com

\begin{abstract}
In the present study estimation of proximate and nutritive analysis of four Azolla cultures were collected from Amravati research station, Guntur, Andhra Pradesh. The four species are A. circinata, A. pinnata, A. rubra and A. Mexicana were optimized for the estimation of biomass production, lipid, phenol, protein and amino acid content. The proximate and analysis reveals the production ranges are as follows Biomass production (11,500 to $\left.18,000 \mathrm{~kg}^{-1} \mathrm{DW}\right)$, amino acid content (17.2 \pm 0.5 to $\left.114.7 \pm 0.6\right)$, phenol $(85.4 \pm 0.7$ to $110.5 \pm 0.6)$ and lipid content $(20.4 \pm 0.5$ to $120.2 \pm 0.9)$ of Azolla species were studied. Growing of these Azolla species maximum yields was showed by A. circinata with 18000 $\mathrm{kg}^{-1}$ DW after 90 days. The average production of amino acid concentration (114.9 \pm 0.6 ) was observed in A. pinnata species. A. Mexicana species containing the highest Protein

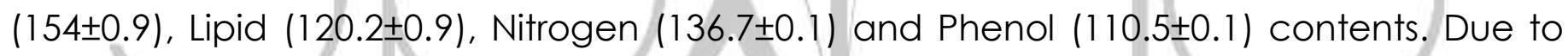
the high nutritive analysis of Azolla the green gold mine is useful for treatment of sewage, Biogas production, bio fertilizer and is also used as poultry feed and fish feed.
\end{abstract}

Keywords: Amino acids, Azolla, Lipid, Nitrogen, Protein. 


\section{Introduction}

Azolla is a fastest growing, unique aquatic fern which floats freely on fresh water surface. As a small, flat, compact mass Azolla floats on water. It grows rapidly by doubling its biomass under optimum conditions for every three days. Worldwide there are nearly eight species of Azolla namely, Azolla caroliliana, Azolla circinata, Azolla japonica, Azolla Mexicana, Azolla microphylla, Azolla nilotica, Azolla pinnata and Azolla rubra. Azolla pinnata is a common species in India. It yields excellent quality of protein more than 4 to 5 times when compared to lucern and hybrid napier (Radhakrishnan et al., 2014). Moreover, the production of biomass is 4 to 5 times more in comparison with hybrid napier and lucern.

Azolla is popularly known as Companion plant, because of its symbiosis with nitrogen fixing cyanobacteria (anabaena azolla) for nearly one thousand years in the fields of paddy. There is no other symbiotic relationship between cyanobacteria and a plant together during reproduction from generation to generation. AzollaAnabaena super organism is unique, as they never depart for almost hundred million of years. It is used as bio fertilizer by rice farmers (Lumpkin \& Plucknett, 1980). Nutritive analysis of dry and organic matter, ash content, crude fiber, cellulose, hemicellulose, lignin, calcium and magnesium were performed according to AOAC (1990) for the potential uses of Azolla (Mahadeva Rao, Nigusie Tesema,

2011).

Recent research studies revealed that the protein content of Azolla plant is $23 \%$ to
$30 \%$ and also $55 \%$ of the amino acid (Gokcinar and Bekcan, 2015). The nutrient requirementfor the optimum growth of tilapia depends on the quality of source, size or age of fish and the energy content of the diet. The average protein requirement varies between 45 and 50, proved by Stickney (1997). In talapia diets, the minimum requirement of dietary lipid is $5 \%$ but by improved growth and efficiency to utilize protein has been reported that for diet with 10\% to

$15 \%$ ( $\mathrm{Ng}$ and Chong, 2004). Azolla, as a valuable protein supplement for many species, which includes ruminants, poultry, fish and pig (Hasan, 2009). The wide distribution of Azolla from the regions of tropical and temperate, there are seven extant species. Some research studies suggested that the Azolla plant has crude protein content of $23 \%-30 \%$ and

$55 \%$ of amino acid (Gokeinar and Bekcan, 2015). Due to the high nutritional values of Azolla may be used in biotechnological and pharmaceutical industries.

Dry Azolla power is utilized as a feed ingredient from various species like, tilapia (Antonie et al., 1986, Abou et al., 2007; Bag and Mahapatra, 2011). The other forms of Azolla as fermented Azolla (Utomo et al., 2001), Azolla protein concentrate (Sundarono, 2006), utilized as feed ingredients in fish diets. High nutritive content and lipid nano paricles based drugs are also important (Prashant et al., 2017; Manikandan and Sarumathy 2018; Mohd. Yaqub, 2014).

However the present study mainly focused on low cost cultivation methods and high nutritive values of Azolla species in our area. A number of fish ponds, poultry forms and farming organizations were located in and around Krishna and Guntur districts, Andhra Pradesh. This is 
why we are selecting locally available Azolla species and were analysed and it is benefit to local farmers. The present study Azolla cultivation and nutritive values of the selected species needs to give more information to fish farmers, poultry industries and researchers.

\section{Materials and Methods}

\section{Sample collection}

In the present study the four different fresh Azolla species namely $A$. circinata, A. pinnata, A. rubra and A. Mexicana were collected from Amravati research station, Guntur, Andhra Pradesh. These species were further propagated in ideal ponds to provide natural day light, temperature conditions were monitored.

\section{Cultivation of Azolla}

Azolla was cultured in plastic trays $(21.7 \times 15.6 \times 8.4 \mathrm{~cm}$, surface area $=340$ $\mathrm{cm} 2$ ) containing one litre of various media. The day/night temperature was $18 \pm 27^{\circ} \mathrm{C}$ and the light intensity was $15 \mathrm{klx}$ with $16 \mathrm{~h}$ light periods. The standard medium (composition of synthetic nutrient solution) contained the following macronutrients: $\mathrm{CaCl} 2 \cdot 2 \mathrm{H} 20 \mathrm{O} 1.00, \mathrm{MgSO} 4$ 7H2O 1.65, K2SO4 0.50, and $\mathrm{NaH} 2 \mathrm{PO} 4$ $2 \mathrm{H} 200.65$ (in mmol L-1). It also contained the following micronutrients: $\mathrm{FeSO} 4$ 7H2O 27.0, $\mathrm{MnCl} 2 \cdot 4 \mathrm{H} 2 \mathrm{O}$ 1.13, CuSO4 $.5 \mathrm{H} 2 \mathrm{O}$ 0.08, ZnSO4 $7 \mathrm{H} 200.19, \mathrm{Na} 2 \mathrm{Mo} 04$ $2 \mathrm{H} 200.05$, and $\mathrm{H} 3 \mathrm{~B} 03$ 5.77. The final $\mathrm{pH}$ of the medium was adjusted to neutral for further reaction.

\section{Bio mass and chemical evaluation of Azolla}

For the estimation of biomass, freshly collected samples were weighed and it was measured by Kg DW ha' ${ }^{-1}$. Sun dried Azolla sample was analyzed for proximate principles viz., dry matter, crude protein, ether extract, total ash, crude fibre and nitrogen free extracts as per the methods described by AOAC (2005).

\section{Harvesting and feeding of Azolla}

On the basis of initial quantity of culture added, environmental conditions and nutrition, Azolla's growth in the pond will be complete in about fifteen to thirty days period. Azolla can be harvested daily after the full growth. Plastic sieves can be used to harvest the biomass yield from the pond's surface. About 800 to 900 grams of fresh Azolla (mean yield per day in a season) can be produced from an area of $6 \times 4$ feet. Azolla can be fed to the livestock either in fresh or dried form.

\section{Estimation of Amino acid concentration}

For the estimation of amino acids fresh Azolla samples were grinded by using mortar and pestle with $6 \mathrm{~N} \mathrm{HCl}$ and transferred the contents to a test tube which was sealed latter. Later it was kept in an oven at $120^{\circ} \mathrm{C}$ for 24 hrs. The contents were filtered, flash evaporated and made up to volume with $0.05 \mathrm{~N} \mathrm{HCl}$. The formed solution was filtered through a $0.45 \mu \mathrm{m}$ pore size filter (Whatman, UK) and injected into an HPLC (Shimadzu-LC 10 AS). In this experiment amino acids were separated in a sodium ion exchange column (Shimadzu-CTO-

6A) fitted with an oven maintained at $60^{\circ} \mathrm{C}$. The post column derivatized amino acids were detected using a ShimadzuFLD-6A-type fluorescence detector (Ishida et al., 1981). Tryptophan was determined separately by a spectrophotometric method (sastry and Tammuru, 1985).

\section{Estimation of Total phenol and lipid content}

One gram of material was used for dry weight determination after further oven drying at $105^{\circ} \mathrm{C}$ for $24 \mathrm{~h}$ of incubation, followed by $1 \mathrm{~h}$ cooling in a desiccator with activated silica. The material was Soxhlet extracted with a 7.5:1 dichloromethane-methanol solution 
for $24 \mathrm{~h}$ with a water bath temperature of $80{ }^{\circ} \mathrm{C}$. Then collected extracts were dried using a rotary evaporator and weighed to determine the amount of 'crude lipids'. After Soxhlet extraction plant residues were collected and dried. Total phenol was determined in triplicate after extraction of $100 \mathrm{mg}$ biomass with 10mL water-acetone 130:70, $\mathrm{v} / \mathrm{v}$ ) for $24 \mathrm{~h}$ at $20^{\circ} \mathrm{C}$ using the reagent Folin-Ciocalteu assay in two technical replicates. (Waterman and Mole, 1994) Tannic acid was used as the calibration standard. Literature data, used for comparison, presented in gallic acid equivalents, were converted to tannic acid equivalents according to the relative reactivity with the FolinCiocalteu reagent.

\section{Estimation of nitrogen and protein content}

The oven-dried plant material was frozen in liquid nitrogen, ground and subsequently freeze dried. Total biomass nitrogen was analyzed in all growth replicates using the Dumas method (according to ISO 16634-1 analytical standard) and total amino acid analyses were performed according to the Ph. EUR 2.2.56 analytical standard (Silliker, Merieux Nutri Sciences, Ede, Netherlands).

\section{Statistical analysis}

Statistical analyses were performed by using SPSS 20 statistics software package. For determining the protein, Nitrogen and amino acid content in between the Azolla species and their effect was analysed by using a two-way analysis of variance (ANOVA). Differences were deemed significant for a $P$-value below 0.05 .
In this study on the basis of growth yield and nutritive analyses for four Azolla species i.e. A. circinata, A. pinnata, A. rubra and $A$. Mexicana, a small production system was designed. By regular harvesting a part of the cultivation area, plants were kept within the linear growth phase to maximize productivity at 90 days of cultivation period. Azolla species were showed a high percentage of biomass content ranging from 11,500 to $18,000 \mathrm{Kg} \mathrm{DW} \mathrm{ha-}$ 1. Biomass production was observed in 15 to 90 days of incubation periods represented in (Table-1). Various other studies are also reported that the important nutritional parameters like nitrogen and amino acid productions in (Morowat and Ghasemi, 2018; Kalita et al., 2013)

Azolla circinata has highest biomass yield of $18,000 \mathrm{Kg} \mathrm{DW} \mathrm{ha}^{-1}$ followed by A. pinnata 13,000 Kg DW $\mathrm{ha}^{-1}$. This concept was also tested by maintaining cultures of $A$. filiculoides and A. pinnata for over 100 days, while harvesting $33 \%$ of the surface area twiceaweek. Azolla filiculoides cultures equilibrated at around $1000 \mathrm{~kg} \mathrm{ha-1}$ before harvest and $670 \mathrm{~kg} \mathrm{ha-1}$ after harvest (Bhaskaran and kannapan, 2015). The present results with agreement of about 1,200 kg/100 m2 of fresh Azolla filiculoides was harvested after culture for 97 days of the plant during cultivation, the density markedly affected the growth rate (Shiomi and Kitoh, 2001). Relatively Brouwer et al., (2018) reported that the Azolla biomass production was high for 154 days of incubation period. 
Table-1: Biomass yield of four Azolla species $\left(\mathrm{Kg}^{-1} \mathrm{DW}\right)$

\begin{tabular}{|l|l|l|l|l|}
\hline Days & A. circinata & A. pinnata & A. rubra & A. mexicana \\
\hline $\mathbf{1 5}$ & 750 & 550 & 450 & 500 \\
\hline $\mathbf{3 0}$ & 6000 & 3700 & 4000 & 3200 \\
\hline $\mathbf{4 5}$ & 12000 & 9000 & 7000 & 7300 \\
\hline $\mathbf{6 0}$ & 16000 & 12000 & 9000 & 9600 \\
\hline $\mathbf{7 5}$ & 17000 & 12500 & 10000 & 10500 \\
\hline $\mathbf{9 0}$ & 18000 & 13000 & 11000 & 11500 \\
\hline
\end{tabular}

*Each data is an average of three replicatesA considerable variation in the moisture content of four Azolla

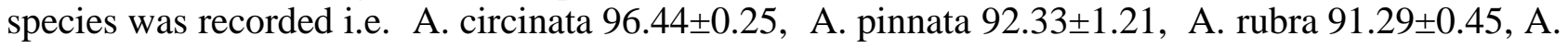
mexicana $98.77 \pm 0.34$. The nitrogen content varied from 0.65 to $1.21 \mathrm{mg} / 10 \mathrm{~g}$ for all the species studied. The total ash content ranged from 2 to $4 \mathrm{mg} / 10 \mathrm{~g}$ was recorded. Similar reports were also reported by (Bhaskaran and kannapan, 2015).

Table-2: Proximate composition of Azolla species (g/100 g )

\begin{tabular}{|l|l|l|l|l|}
\hline Azolla species & Biomass & Moisture & Nitrogen & Ash content \\
& (90 days $)$ & & content & \\
\hline A. circinata & 18000 & $96.44 \pm 0.25$ & $1.21 \pm 0.01$ & $4 \pm 0.03$ \\
\hline A. pinnata & 13000 & $92.33 \pm 1.21$ & $0.78 \pm 0.05$ & $3 \pm 0.05$ \\
\hline A. rubra & 11000 & $91.29 \pm 0.45$ & $0.65 \pm 0.03$ & $2 \pm 0.07$ \\
\hline A. mexicana & 11500 & $98.77 \pm 0.34$ & $0.89 \pm 0.01$ & $4 \pm 0.04$ \\
\hline
\end{tabular}

* The overall model is significant with $\mathrm{p}<0.05$ 
Amino acid content was determined by the four species of Azolla was represented in Table 3. A. pinnata showed essential amino acid cysteine ranged from $17.2 \pm 0.5$ to $114.7 \pm 0.6$. Maximum alanine production 70.2 \pm 5.1 was recorded by A. circinata. There are twelve essential amino acids were represented in the study. Much variation was observed in the amino acid production by all the species studied. The tryptophan ranges from $39.7 \pm 0.3$ to

62.6 \pm 0.8 . A. mexicana contain high proportion of glutamic acid (95.4 \pm 0.1$)$. Another species A. rubra contain high phenyl alanine content 47.6 \pm 0.5 . The ideal pattern of adult plants was analyzed, compared to favourable and well exceeded with the except for phenylalanine and tryptophan was reported.

From the results it was tested for total phenols and lipids content of four Azolla species showed much variation. Maximum levels of phenol $\left(110.5 \pm 0.1 \mathrm{Kg}^{-}\right.$ 1 DW), lipids (120.2 $\pm 0.9 \mathrm{Kg}^{-1}$ DW) was observed in Azolla mexicana (Table-4). The rest of the species also showed less quantity of phenols and lipids. The dry weight of Azolla species biomass content of lipids (79-100 $\left.\mathrm{Kg}^{-1} \mathrm{DW}\right)$ and phenols (21- $\left.69 \mathrm{Kg}^{-1} \mathrm{DW}\right)$ showed maximum levels was reported by Brouwer et al., 2018. 
Table-3: Amino acid concentration in biomass of Azolla species

\begin{tabular}{|l|l|l|l|l|}
\hline Amino acid & A. circinata & A. pinnata & A. rubra & A. mexicana \\
\hline Alanine & $65.7 \pm 0.1$ & $70.2 \pm 5.1$ & $59.2 \pm 0.1$ & $62.4 \pm 0.5$ \\
\hline Arginine & $70.6 \pm 0.3$ & $71.4 \pm 0.9$ & $70.03 \pm 0.7$ & $65.4 \pm 0.6$ \\
\hline Gystine & $102.3 \pm 5.2$ & $114.7 \pm 0.6$ & $103.4 \pm 0.4$ & $98.0 \pm 0.8$ \\
\hline Glutamic acid & $94.3 \pm 0.5$ & $42.9 \pm 0.3$ & $45.4 \pm 0.5$ & $42.5 \pm 0.2$ \\
\hline Isoleucine & $39.4 \pm 0.3$ & $36.6 \pm 0.7$ & $32.0 \pm 0.6$ & $39.3 \pm 0.7$ \\
\hline Methionine & $18.2 \pm 0.9$ & $17.2 \pm 0.5$ & $22.0 \pm 0.1$ & $23.0 \pm 0.8$ \\
\hline Proline & $33.2 \pm 0.5$ & $33.4 \pm 0.3$ & $36.9 \pm 0.6$ & $40.9 \pm 0.5$ \\
\hline Phenyl alanine & $40.6 \pm 0.2$ & $45.7 \pm 0.5$ & $47.6 \pm 0.5$ & $48.3 \pm 0.3$ \\
\hline Serine & $76.0 \pm 0.1$ & $50.4 \pm 0.5$ & $72.4 \pm 0.2$ & $69.5 \pm 0.2$ \\
\hline Threonine & $55.4 \pm 0.3$ & $65.3 \pm 0.7$ & $68.4 \pm 0.1$ & $40.6 \pm 0.3$ \\
\hline Tryptophan & $62.6 \pm 0.8$ & $39.7 \pm 0.3$ & $49.4 \pm 0.4$ & $55.7 \pm 0.7$ \\
\hline
\end{tabular}

* The overall model is significant with $\mathrm{p}<0.05$ 
Table-4: Total phenol and lipid content $\left(\mathrm{Kg}^{-1} \mathrm{DW}\right)$ of Azolla species

\begin{tabular}{|l|l|l|l|l|}
\hline Estimation of & A. circinata & A. pinnata & A. rubra & A. Mexicana \\
phenol\& lipid & & & & \\
\hline Phenol & $85.4 \pm 0.7$ & $101.6 \pm 0.3$ & $94.5 \pm 0.7$ & $110.5 \pm 0.1$ \\
\hline Lipid & $20.4 \pm 0.5$ & $50.5 \pm 0.2$ & $60.5 \pm 0.8$ & $120.2 \pm 0.9$ \\
\hline
\end{tabular}

* The overall model is significant with $\mathrm{p}<0.05$ From the results nitrogen and protein content of four Azolla species showed variations. Maximum nitrogen $(136.7 \pm 0.1)$ and protein $(154.3 \pm 0.3)$ was showed by A. mexicana (Table-5). Similarly the crude protein content determined was considerably high when compared with crude protein content of water hyacinth (Eicchornia crassipes) and Azolla Mexicana (Brouwer et al., 2018). The major advantage of Azolla over established crops derives from the combination of nitrogen and high yields may expect. Considerable nitrogen and protein content was produced by all the four species studied.

Table-5: Nitrogen and protein concentrations Azolla species

\begin{tabular}{|l|l|l|l|l|}
\hline $\begin{array}{l}\text { Estimation of } \\
\text { Nitrogen\& } \\
\text { Protein }\end{array}$ & A. circinata & A. pinnata & A. rubra & A. mexicana \\
\hline Nitrogen & $98.6 \pm 0.6$ & $111.05 \pm 0.3$ & $123.4 \pm 0.9$ & $136.7 \pm 0.1$ \\
\hline Protein & $132.2 \pm 0.7$ & $120.7 \pm 0.5$ & $115.7 \pm 0.8$ & $154.3 \pm 0.3$ \\
\hline
\end{tabular}

* The overall model is significant with $\mathrm{p}<0.05$ 


\section{Conclusion}

Results reveal that the cultivated four Azolla species showed much variation in their biomass production. Nutritive analysis of A. mexicana produced maximum content of nitrogen, phenols, Protiens and lipids. Due to high nutritional value of this $A$. mexicana useful for fresh feed stock and recommend for poultry and fish farms for better yield.

\section{Acknowledgement}

Author would like to greatly thankful the department of Botany and Andhra Christian College, Guntur for providing necessary facilities to complete this research work.

\section{References}

RADHAKRISHNAN S, SARAVANA BP, SEENIVASAN C, SHANTHI R, MURALISANKAR T. Replacement of fishmeal with Spirulina platensis, Chlorella vulgaris and Azolla pinnata on nonenzymatic and enzymatic antioxidant activities of Macrobrachium rosenbergii. The J Basic Appl Zool, 2014; 67: 25-33.

LUMPKIN, T. A. \& D. L. PLUCKNETT, . Azolla: botany, physiology and use as green manure. Econom. Bot, 1980, 34: 111153.AOAC, Official methods of analysis, 15th edn., 1990, Vol II.

\section{U.S. MAHADEVA RAO, NIGUSIE TESEMA.} Biochemical Influence of Soaking and Blanching on Nutritional and Phytotherapeutic Properties of Ethiopian abish (Trigonella foenumgraecum) Seed Flour. Research J. Pharm. and Tech. 4(7): July 2011; Page 11541158.
GOKCINAR, N.C., BEKCAN. S., he effects of partially replacing fishmeal with Azolla (Azolla Sp.) on growth parameters of shabbout fish (Tor grypus H. 1843). J. Appl. Biol. Sci. 2015; 9(1): 43-46.

STICKNEY, R.R., Tilapia nutrition, feeds and feeding. Tilapia Aquacult. Ame.1997; 1: 34-

54.

NG, W.K., CHONG, C.Y. An overview of lipid nutrition with emphasis on alternative lipid sources in tilapia feeds. Fish Nutr. Lab. School. Biol. Sci. 2004; University Sains Malaysia Penang 11800, Malaysia.

HASAN MR, CHAKRABARTI R. Use of algae and aquatic macrophytes as feed in small- scale aquaculture: A review. FAO Fisheries and Aquaculture technical paper, 2009; 531. FAO, Rome, Italy.

ANTOINE, T., WERY, P., MICHA, J.C., VAN HOVE, C., Comparison of the growth and chemical composition of Oreochromis niloticus (tilapia) and Cichlasoma melanurum (Theraps) fed with Azolla. Aquacult. 1987; 66: 181-196.

ABOU, Y., FIOGBE, E.D., MICHA, J.C., A preliminary assessment of growth and production of Nile tilapia, Oreochromis niloticus (L) fed Azolla based diets in earthen ponds. J. Appl. Aquacult. 2007; 19(4): 55-69.

BAG, M.P., MAHAPATRA, S.C., RAO, P.S., CHAKRABARTY, D., Making aquatic weed as potential feed for Nile tilapia Oreochromis niloticus (L) and its impact on fatty acid profile. Int. Res. Pharma. Pharmacol. 201 1; 1 (8): 194- 202.

UTOMO, N.B.P., EKASARI, N.J., Fermentation of Azolla sp. leaves and the utilization as a feed ingredient of tilapia 
Oreochromis sp. J. Aquacult. Indonesia. $2011 ; 10(2)$ : 137-143.

SUDARYONO, A., Use of Azolla (Azolla pinnata) meal as a substitute for defatted soybean meal in diets of juvenile black tiger shrimp (Penaeus monodon). J. Coast. Dev. 2006;

9(3):145- 154.

PRASHANT S. WAKE, M. D. KSHIRSAGAR. Design and Characterization of Solid Lipid Nanoparticle Based Transdermal Drug Delivery System. Asian J. Res. Pharm. Sci. 2017;7(2): 87-91.

MANIKANDAN. R, SARUMATHY. S. Clinical study on assessment of lipid Profile and renal function in type 2 Diabetic patientsA Retrospective Study. Research J. Pharm. and Tech 2018; 11 (4): 1624-1626.

AOAC. Association of Official Analytical Chemists. Official Methods of Analysis. 2005; 18th Edition, Maryland, USA.

ISHIDA, Y., FUJITA, T. AND ASAI, K. NeW detection and separation method for amino acids by high-performance liquid chromatography. Journal of Chromatography A, 1981;

204:143-148.

SASTRY, C.S.P. AND TUMMURU, M.K., Spectrophotometric determination of tryptophan in proteins. JOURNAL OF FOOD SCIENCE AND TECHNOLOGY- MYSORE，1985; 22(2):146147.

WATERMAN PG AND MOLE S, Analysis of Phenolic PlantMetabolites. Blackwell Scientific, Oxford, 1994.

BHASKARAN, S.K. AND KANNAPAN, P. Nutritional composition of four different species of Azolla. European Journal of Experimental Biology, 2015; 5(3):6-12. as fish feed. Soil science and plant nutrition, 2001; 47(1):27-34.

BROUWER, P., SCHLUEPMANN, H., NIEROP, K.G., ELDERSON, J., BIJL, P.K., VAN DER MEER, I., DE VISSER, W., REICHART, G.J., SMEEKENS, S. AND VAN DER WERF, A., Growing Azolla to produce sustainable protein feed: the effect of differing species and $\mathrm{CO} 2$ concentrations on biomass productivity and chemical composition. Journal of the Science of Food and Agriculture, 2018; 98(12):47594768.

SHIOMI, N. AND KITOH, S. Culture of Azolla in a pond, nutrient composition, and use 